Portland State University

PDXScholar

Mechanical and Materials Engineering Faculty

Publications and Presentations

Mechanical and Materials Engineering

$11-2016$

\title{
Bioaerosol Deposition on an Air-Conditioning Cooling Coil
}

Yan Wu

Shandong University of Technology

Ailu Chen

Nanyang Technological University

Irvan Luhung

Nanyang Technological University

Elliott T. Gall

Portland State University, gall@pdx.edu

Qingliang Cao

Nanyang Technological University

See next page for additional authors

Follow this and additional works at: https://pdxscholar.library.pdx.edu/mengin_fac

Part of the Materials Science and Engineering Commons, and the Mechanical Engineering Commons Let us know how access to this document benefits you.

\section{Citation Details}

Wu, Y., Chen, A., Luhung, I., Gall, E. T., Cao, Q., Chang, V. W., \& Nazaroff, W. W. (2016). Bioaerosol deposition on an air-conditioning cooling coil. Atmospheric Environment, 144257-265. doi:10.1016/ j.atmosenv.2016.09.004

This Post-Print is brought to you for free and open access. It has been accepted for inclusion in Mechanical and Materials Engineering Faculty Publications and Presentations by an authorized administrator of PDXScholar.

Please contact us if we can make this document more accessible: pdxscholar@pdx.edu. 


\section{Authors}

Yan Wu, Ailu Chen, Irvan Luhung, Elliott T. Gall, Qingliang Cao, Victor Wei-Chung Chang, and William W. Nazaroff 
A University of California author or department has made this article openly available. Thanks to the Academic Senate's Open Access Policy, a great many UC-authored scholarly publications will now be freely available on this site.

Let us know how this access is important for you. We want to hear your story!

http://escholarship.org/reader_feedback.html

\section{8}

Peer Reviewed

Title:

Bioaerosol deposition on an air-conditioning cooling coil

Journal Issue:

ATMOSPHERIC ENVIRONMENT, 144

\section{Author:}

$\mathrm{Wu}, \mathrm{Y}$

Chen, A

Luhung, I

Gall, ET

Cao, Q

Chang, VW-C

Nazaroff, WW

\section{Publication Date:}

11-01-2016

\section{Series:}

UC Berkeley Previously Published Works

\section{Also Available:}

Recent Work

\section{Permalink:}

http://escholarship.org/uc/item/8rt2x9ds

\section{DOI:}

https://doi.org/10.1016/j.atmosenv.2016.09.004

\section{Keywords:}

Bioaerosols, DNA, Deposition, Cooling coil, Condensate water

\section{Local Identifier:}

1758289

\section{Copyright Information:}

All rights reserved unless otherwise indicated. Contact the author or original publisher for any necessary permissions. eScholarship is not the copyright owner for deposited works. Learn more at http://www.escholarship.org/help_copyright.htm|\#reuse

eScholarship

University of California
eScholarship provides open access, scholarly publishing services to the University of California and delivers a dynamic research platform to scholars worldwide. 


\section{Bioaerosol Deposition on an Air-Conditioning Cooling Coil}

2

Yan $\mathrm{Wu}^{\mathrm{a}, \mathrm{b}, *}$, Ailu Chen ${ }^{\text {b, c }}$, Irvan Luhung ${ }^{\mathrm{b}, \mathrm{c}}$, Elliott T. Gall ${ }^{\mathrm{b}, \mathrm{d}}$, Qingliang Cao ${ }^{\mathrm{c}}$, Victor Wei-Chung Chang ${ }^{b, c}$, and William W Nazaroff ${ }^{b, e}$

${ }^{a}$ School of Environmental Science and Engineering, Shandong University, Jinan 250100, China

${ }^{\mathrm{b}}$ SinBerBEST Program, Berkeley Education Alliance for Research in Singapore (BEARS), Singapore

${ }^{\mathrm{c}}$ School of Civil and Environmental Engineering, Nanyang Technological University, Singapore

${ }^{\mathrm{d}}$ Department of Mechanical and Materials Engineering, Portland State University, Portland, OR, USA

${ }^{\mathrm{e}}$ Department of Civil and Environmental Engineering, University of California, Berkeley, CA, USA

* Corresponding author:

Yan $\mathrm{Wu}, \mathrm{PhD}$

Email:wuyan@sdu.edu.cn

Phone: +8615624591836

School of Environmental Science and Engineering, Shandong University, Jinan 250100, China

\section{Abstract}

This study is concerned with the role of a fin-and-tube heat exchanger in modifying microbial indoor air quality. Specifically, depositional losses of ambient bioaerosols and particles onto dry (not cooled) and wet (cool) coil surfaces were measured for different airspeeds passing through the test coil. Total, bacterial and fungal DNA concentrations in condensate water produced by a wet coil were also quantified by means of fluorescent dsDNA-binding dye and qPCR assays. Results revealed that the deposition of bioaerosols and total particles is substantial on coil surfaces, especially when wet and cool. The average deposition fraction was 0.14 for total DNA, 0.18 for bacterial DNA and 0.22 for fungal DNA on the dry coil, increasing to 0.51 for total DNA, 0.50 for bacterial DNA and 0.68 for fungal DNA on the wet coil. Overall, as expected, deposition fractions increased with increasing particle size and increasing airspeed. Deposited DNA was removed from the cooling coil surfaces through the flow of condensing water at a rate comparable to the rate of direct 
36 deposition from air. A downward trend of bacterial and fungal DNA measured in condensate water over time provides suggestive evidence of biological growth on heat exchangers during nonoperational times of a ventilation system. This investigation provides new information about bioaerosol deposition onto a conventional fin-and-tube cooling coil, a potentially important factor influencing indoor exposure to microbial aerosols in air-conditioned

41 buildings.

42 Key words: Bioaerosols, DNA, Deposition, Cooling coil, Condensate water

\section{Introduction}

The fin-and-tube heat exchanger is a ubiquitous component of air-conditioning systems in mechanically ventilated buildings, employed to condition the temperature and humidity of air delivered to indoor environments (Pongsoi et al., 2014; Tang et al., 2016). In warm seasons for temperate and subtropical climates, and during the whole year for tropical climates, the heat exchanger (commonly referred to as a cooling coil) is utilized to cool and dehumidify the air (Chen et al., 2016). The aggregate energy transfer at this location across all airconditioned buildings accounts for much of the total energy demand and also peak energy demand during warm conditions in cities worldwide (Siegel and Carey, 2001).

$$
\text { The air supplied to mechanically ventilated buildings inevitably passes over heat- }
$$
exchanger surfaces and the interaction between the air and the cooling coil surfaces can modify air quality, both for the flow path from outdoors to indoors and for recirculating airflows. Modeling and experimental studies reveal that some particles in the airstream could deposit onto the heat exchanger surfaces (Siegel and Nazaroff, 2003; Waring and Siegel, 2008; Gröhn et al., 2009; Grigonyte et al., 2014). Some studies also have suggested that previously deposited particles on coil surfaces could become reentrained in the airflow and constitute a secondary source of indoor particles (Siegel and Carey, 2001; Siegel, 2002). 
Important knowledge gaps remain concerning how heat-exchanger surfaces in airconditioning and mechanical ventilation (ACMV) systems influence indoor air quality. With regard to microbial air quality, it is important to note that heat exchanger surfaces are regularly wet in air-conditioning seasons in areas with moderate or elevated humidity.

Observational studies have documented that the use of cooling coils could increase bioaerosol levels in indoor environments, suggesting a potential role of cooling coils as a source of indoor bioaerosols (Hugenholtz and Fuerst, 1992; Abe, 1998; Bluyssen et al., 2003; Jo and Lee, 2008). In addition to the potential release of biological materials, another process on cooling coil surfaces might also be important. Biological aerosol particles may deposit on cooling coil surfaces and be removed from air. Some fraction of the deposited particles may be transferred to the condensate water and be removed from the indoor environment through the drainage process. However, only one prior study has discussed the possibility of such bioaerosol deposition on cooling coil surfaces (Siegel and Walker, 2001). To the best of our knowledge, no work has yet been published that experimentally investigates bioaerosol deposition processes onto an air-conditioning cooling coil.

The objective of this research is to provide a systematic experimental investigation of bioaerosol transformations across a typical fin-and-tube heat exchanger in a model vaporcompression ACMV system similar to those used in modern air-conditioned buildings in tropical environments. In brief, the deposition fractions of ambient bioaerosols that include bacterial and fungal aerosol particles, size-resolved total particles, as well as monodisperse polystyrene latex (PSL) particles were measured for dry (not cooled) and wet (cooled) coils. Total, bacterial and fungal DNA concentrations in condensate water draining from a wet coil were also analyzed using a Qubit fluorometer and real-time PCR system. This study contributes to a better understanding of bioaerosol transformation processes as pertinent influences of indoor microbial air quality in air-conditioned buildings. 
85

\section{Materials and Methods}

\subsection{Experimental apparatus and test procedure}

This work was conducted using a laboratory apparatus (see Figure 1) in which a fin-andtube cooling coil system was situated between connecting upstream and downstream ducts. The cooling coil was of conventional design, comprising four rows of cylindrical copper refrigerant tubes, which were oriented horizontally and to which were attached vertical aluminum fins. The apparatus had a fin pitch of 3.1 fins/cm (within the common range of 2.4 to 7.1 fins $/ \mathrm{cm}$ ) and a center-to-center tube spacing of $7.6 \mathrm{~cm}$. The corrugated fins were 0.1 mm thick and $44 \mathrm{~mm}$ deep in the direction of air flow. The copper tubes, which were inserted into aluminum vertical fins with full fin collars, had an outer diameter of $1.59 \mathrm{~cm}$ and a 0.09 cm thick wall.

The test apparatus was sited in a laboratory that was open to ambient air during working hours. A variable speed fan, installed at the inlet of the test coil system, pushed air through $3.6 \mathrm{~m}$ of straight $42 \mathrm{~cm} \times 42 \mathrm{~cm}$ square upstream duct. The air then passed through the finand-tube heat exchanger which has the same area as the upstream duct $(42 \mathrm{~cm} \times 42 \mathrm{~cm})$, followed by another $3.6 \mathrm{~m}$ section of straight $42 \mathrm{~cm} \times 42 \mathrm{~cm}$ square duct downstream. Air speeds inside air-handling unit cooling coil systems commonly range from 1 to $4 \mathrm{~m} / \mathrm{s}$ (Siegel and Nazaroff, 2003; Siegel and Carey, 2001). In this work, we used the variable speed fan to test three air speeds for the open sections of the ducts: 1.0, 1.5 and $2 \mathrm{~m} / \mathrm{s}$. If not otherwise specified, the results presented here are for an air speed of $1.5 \mathrm{~m} / \mathrm{s}$, which converts to a mass flow rate of $1030 \mathrm{~kg} / \mathrm{h}$ of dry air passing through the coil surfaces (Rim et al., 2015).

This work was conducted in Singapore, where the ambient dew point temperature is consistently high. Dry-bulb temperatures typically range from 25 to $32{ }^{\circ} \mathrm{C}$ and the ambient relative humidity $(\mathrm{RH})$ was always above $75 \%$ during these experiments. Continuous measurements were made of air temperatures, $\mathrm{RH}$ and air speeds using air velocity meters 
110 (VELOCICALC Air Velocity Meter Model 9545, TSI Inc., Shoreview, MN, USA) at two

111 cross-sections that were positioned $0.5 \mathrm{~m}$ upstream and $0.5 \mathrm{~m}$ downstream of the cooling coil.

112 We utilized nine measurement locations defining a uniform grid through each of the two

113 cross-sections of the duct. Airflow parameter values are reported in Figure S1 in the

114 supporting information. When the cooling coil was operated, surface temperatures were also

115 continually measured using digital thermometers (Fluke 54 II B Dual Input Digital

116 Thermometer, Fluke Corporation, WA, USA). The measurement points were located on the

117 top of the side face for each of the four rows of copper refrigerant tubes (as marked by red

118 triangles in Figure 1). Results are shown in Figure S2.

119 In this work we studied two operational conditions: cooling coil off (“dry coil," which refers

120 to a coil that is not being cooled and that is also not wet) and cooling coil on ("wet coil,"

121 which refers to a cooled coil onto which condensation occurs continuously). For the dry coil,

122 the fan was on and the compressor was off for all experimental time. The entire system was

123 dry and nominally isothermal. Conversely, for the wet coil, the fan and the compressor were

124 on at all times. Cooling was achieved, and condensate water was produced, by sending the

125 coolant R-134a through the cooling coil system. Both modes of operation were tested in

126 steady state with regard to thermal conditions.

127 In our experiments, the surface temperatures of the wet coil $\left(16-6^{\circ} \mathrm{C}\right.$ from Row 1 to Row 4 , 128 see Figure S2) were much lower than those of dry coil (room temperature, $\sim 26^{\circ} \mathrm{C}$ ). For all

129 experiments, the cooling system as well as the fan were operated from 8 AM to 7 PM,

130 Monday through Friday, and were off for other times to simulate one type of typical

131 operation in commercial buildings in Singapore (Rim et al., 2015). In this work, we found the

132 wet coil could produce the condensate water at a relatively stable flow rate after the 
133 compressor was on for an hour. So, for the wet coil condition, all measurements were

134 conducted starting from 9 AM, i.e. after 60 min of coil operation.

135

136

137

138

139

141

142

143

144

145

\subsection{Leakage test of the coil system}

Before conducting the experiments, we cleaned the cooling coil with freshly purified water and checked the test system for cleanliness and for leakage. We installed a HEPA filter at the inlet of the system to remove particles from the ambient air and monitored the particle concentrations both for upstream and downstream of the dry coil using optical particle counters (OPC, AeroTrak® Handheld Particle Counter Model 9306, TSI Inc., Shoreview, MN, USA). The ambient particle concentrations were also monitored at the same time using three OPCs. Results confirmed that the maximum leakage rate was small enough to not significantly influence the study objectives, as shown in Figure S3.

\subsection{Particle concentration monitoring}

\subsubsection{Total particles}

Size-resolved particle concentrations were monitored upstream and downstream of the cooling coil with OPCs and scanning mobility particle sizers (NanoScan SMPS nanoparticle sizer 3910, TSI Inc., Shoreview, MN, USA) for both dry and wet coil conditions. The upstream and downstream sampling arrays were located in the cross-sectional area of the duct $2.6 \mathrm{~m}$ upstream and $2.6 \mathrm{~m}$ downstream of the test coil, respectively. Each sampling array comprised three equidistant vertical columns of Teflon sampling tubes into which were drilled four equally spaced holes. The inner diameter of holes was selected based on the air speed inside the duct to approximately achieve isokinetic sampling. The OPC measures particle number concentrations in six size ranges: $0.3-0.5 \mu \mathrm{m}, 0.5-1.0 \mu \mathrm{m}, 1.0-2.5 \mu \mathrm{m}, 2.5-5$ $\mu \mathrm{m}, 5-10 \mu \mathrm{m}$ and 10-25 $\mu \mathrm{m}$. The SMPS was measured size-resolved particle concentrations spanning the diameter range 10 to $420 \mathrm{~nm}$. 


\subsubsection{Monodisperse polystyrene latex (PSL) particles}
To investigate in more detail the size-dependence of particle deposition on the cooling coil, we also measured deposition using monodisperse spherical PSL particles (JSR Trading Co., Ltd., Tokyo, Japan) across both the dry and wet coil. The PSL suspension (concentration $=10^{8}$ particles $\left./ \mathrm{mL}\right)$ was aerosolized using a Collison nebulizer (CN24, BGI Inc., Waltham, MA), which was operated at a flow rate of $2.5 \mathrm{~L} / \mathrm{min}$ with nitrogen gas. The resulting aerosol flow was delivered into the upstream zone of the test system. During the PSL tests, a HEPA filter was installed at the duct inlet to remove ambient particles from the test system. Airborne PSL concentrations were measured upstream and downstream of the coil with OPCs in the same locations in the duct as total particles described in $§ 2.3 .1$. Four PSL diameters were tested independently: $0.8,2.0,3.3$ and $5.1 \mu \mathrm{m}$. Nine replicate experiments were conducted for each size.

\subsection{Bioaerosol sampling}

To collect bioaerosol samples for subsequent analysis, during each experimental trial, air upstream and downstream of the coil was isokinetically sampled for 9-h periods (daily from 9 AM to 6 PM) using in-line sterilized membrane filters (Super 200, Pall Corporation, Michigan, USA) at a sampling flow rate of $15 \mathrm{~L} / \mathrm{min}$ with similar sampling arrays as for particles (see §2.3.1). The air sampling flow rate was calibrated using a Gilibrator-2 (Sensidyne, Inc., Petersburg, FL, USA) both before and after sampling. We also placed a quality-control blank filter in a holder and left it exposed in the ambient air near the test coil system for 9 hours.

We compared the in-line sampling method with open-face filter sampling (upstream of the coil) to check the possibility that some of the bioaerosol DNA might have deposited on the sampling tube before reaching the filter. In the verification test, the middle of the three Teflon sampling tubes was removed and replaced by two open-face filter holders, which were 
182 directly located in the center of cross-sectional area of the duct. The two in-line sampling

183 filters and the two open-face filters were simultaneously operated with their pumps to collect

184 bioaerosols at a standard flow rate of $15 \mathrm{~L} / \mathrm{min}$ for 9 hours. All bioaerosol samples were

185 analyzed with the molecular methods described in $\S 2.6$. Results of this verification test

186 showed good comparability between the open-face and in-line samplers, as presented in

187 Table S1.

188 2.5. Collection of condensate water produced by wet AC cooling coil

189 Condensate water samples of $1-\mathrm{L}$ volume were collected at intervals of 60 min (collection

190 times $=9$ AM through 2 PM) using sterile centrifuge tubes (Corning, Inc., New York, USA)

191 for all experiments in which the coil was cooled. In addition, 500-mL samples of condensate

192 water from an AHU air-conditioning system used in a commercial building in Singapore

193 were also collected at 8 AM, 2 PM and 6 PM on Fridays for three successive weeks. In

194 contrast to the laboratory test system, the commercial-building AHU processed return air

195 from offices that had high human occupancy. All water samples were analyzed with the

196 molecular methods described in $\$ 2.6$.

197 2.6. DNA extraction and quantification

198 After sampling, DNA was extracted from membrane filters used for air sampling and

199 from the blank control filters. Condensate water was first processed using filter funnels with

$200 \quad 0.22 \mu \mathrm{m}$ membrane filters (MO BIO Laboratories, Carlsbad, CA, USA) and then these filters

201 were extracted for DNA using the same procedure as for air-sampling filters. Extractions

202 were performed using the PowerWater ${ }^{\circledR}$ DNA Isolation Kit (MO BIO Laboratories, Carlsbad,

203 CA, USA). We followed the manufacturer's recommended procedures with an additional step

204 of water bath sonication to improve DNA yield (Luhung et al., 2015). To briefly summarize,

205 first, the filter was placed into a 5-ml tube with $1 \mathrm{ml}$ preheated PW1 (a strong lysing reagent), 
followed by incubation in a $65{ }^{\circ} \mathrm{C}$ sonication water bath for $30 \mathrm{~min}$ and centrifugation at $4000 \times \mathrm{g}$ for 1 minute. Avoiding the pellet at the bottom of the tube, the supernatant was transferred to a clean 2-ml collection tube. Second, $200 \mu 1$ of PW2 solution was added to the suspension to remove non-DNA organic and inorganic materials, including humic acid, cell

210 debris, and proteins. After incubating at $4{ }^{\circ} \mathrm{C}$ for $5 \mathrm{~min}$, samples were centrifuged again at

$21113,000 \times \mathrm{g}$ for $1 \mathrm{~min}$. The remaining extraction steps were performed according to the 212 standard MO-BIO PowerWater ${ }^{\circledR}$ DNA isolation protocol. Finally, $60 \mu \mathrm{L}$ of solution from 213 each sample was saved for subsequent DNA quantification and amplification. All manipulations of the samples were performed in a Biosafety Level II cabinet (Sterilchem GARD, Baker Co., Sanford, Maine).

217 fluorescent dsDNA-binding dye assay (Qubit Fluorometer, Invitrogen, Carlsbad, CA, USA)

218 according to manufacturer's procedures. Concentrations of DNA extracted from blank 219 samples were consistently below the detection limit of Qubit fluorometer, which indicates that there was no significant DNA contributed by laboratory personnel.

222 were also quantified using qPCR. Bacterial universal forward primer 5'-

223 TCCTACGGGAGGCAGCAGT-3' $\left(\mathrm{T}_{\mathrm{m}}, 59.4^{\circ} \mathrm{C}\right)$, reverse primer $5^{\prime}-$

224 GGACTACCAGGGTATCTAATCCTGTT-3' $\left(\mathrm{T}_{\mathrm{m}}, 58.1^{\circ} \mathrm{C}\right)$ and probe (6-FAM)-5'-

225 CGTATTACCGCGGCTGCTGGCAC-3’ -(TAMRA) $\left(\mathrm{T}_{\mathrm{m}}, 69.9^{\circ} \mathrm{C}\right)$ were used for bacterial

226 DNA amplification (Nadkarni et al., 2002). Universal forward primer 5'-

227 GGRAAACTCACCAGGTCCAG-3' FungiQuant-F $\left(\mathrm{T}_{\mathrm{m}}, 62.5^{\circ} \mathrm{C}\right)$, reverse primer $5^{\prime}$ -

228 GSWCTATCCCCAKCACGA-3' FungiQuant-R $\left(\mathrm{T}_{\mathrm{m}}, 56.5^{\circ} \mathrm{C}\right)$, and probe $(6 \mathrm{FAM}) 5^{\prime}-$

229 TGGTGCATGGCCGTT-3'(MGBNFQ) $\left(\mathrm{T}_{\mathrm{m}}, 68^{\circ} \mathrm{C}\right)$, designed by Liu et al. (2012), were 230 used for fungal DNA amplification. The amplification and detection of genes was performed 
using Applied Biosystems Step-one real-time PCR system and the qPCR conditions described by Liu et al. (2012) were used in this study. 26644) suspensions were serially diluted into $10^{-1}, 10^{-2}, 10^{-3}, 10^{-4}$ and $10^{-5}$, respectively.

235 These dilutions were then quantified with the Qubit fluorometer and used as bacterial and 236 fungal DNA standards for qPCR. The bacterial and fungal suspensions that we used were separately prepared following procedures described in previous studies (Wu and Yao, 2010;

238 Liang et al., 2012).

\subsection{Quantifying bioaerosol and particle deposition fractions}

The deposition fraction of total particles, PSL and bioaerosol DNA on the cooling coil, $\eta$,

241 was evaluated using this equation:

$$
\eta=\left[1-\left(C_{\text {downstream }} / \mathrm{C}_{\text {upstream }}\right)\right]
$$

243 where $C_{\text {upstream }}$ is the analyte concentration of the air upstream and $C_{\text {downstream }}$ is the analyte

244 concentration of the air downstream of the cooling coil. Bioaerosol deposition fractions were 245 calculated using measured DNA concentrations from the sampling filters. The deposition

246 fraction for particles and PSL was determined from measured number concentrations.

\section{2.8. Quantifying condensate generation rate and calculated DNA concentration in}

\section{8 condensate water}

249 The generation rate of condensate water depends on environmental conditions and can be 250 calculated from air temperature, relative humidity and air flow rate data, as shown in 251 equation (2):

$$
Q_{\text {condensate }}=F_{\text {dryair }} \times\left(W_{\text {upstream }}-W_{\text {downstream }}\right) / \rho
$$

253 In this equation, $Q_{\text {condensate }}$ is the volumetric flow rate of condensate water from the cooling coil, under steady drainage conditions (L/min), $F_{\text {dryair }}$ is mass flow rate of dry air through the 
255 coil $\left(\mathrm{kg} \mathrm{min}^{-1}\right), W$ is the humidity ratio of the air upstream and downstream of the coil $(\mathrm{kg}$ of water vapor per $\mathrm{kg}$ of dry air), and $\rho$ is the density of liquid water (1.0 kg liquid water per $\mathrm{L})$.

257 The humidity ratio is calculated using equation (3):

$$
W=0.622 P_{\mathrm{w}} /\left(P-P_{\mathrm{w}}\right)
$$

259 where $P_{\mathrm{w}}$ is the partial pressure of water vapor, evaluated from the relative humidity and air 260 temperature (see, e.g., Table 1 in Rim et al., 2015) and $P$ is the total air pressure.

261 We computed a benchmark estimate of the DNA concentration in condensate water by 262 assuming that the DNA lost from the airstream was transferred quantitatively to the draining 263 condensate. The measured concentration could be compared to this benchmark to provide an 264 indication of whether (a) much of the deposited DNA was retained on the coil or (b) DNA 265 was shed as an outcome of microbial replication on coil surfaces. The benchmark estimate is computed from equation (4):

$$
C_{\text {benchmark }}=F_{\text {dryair }} \times\left(C_{\text {upstream }}-C_{\text {downstream }}\right) / Q_{\text {condensate }}
$$

268 Here, $C_{\text {benchmark }}$ is the predicted DNA concentration in the condensate water (mass of DNA

269 per L) based on the assumption of no loss or gain of DNA owing to interactions with cooling

270 coil surfaces, $C_{\text {upstream }}$ is the DNA concentration of the air upstream and $C_{\text {downstream }}$ is the

271 DNA concentration of the air downstream of the cooling coil, both expressed as mass of

272 DNA per mass of dry air.

\section{2.9. Statistical Analysis}

274 The experimental data were analyzed by a paired $t$-test utilizing SigmaPlot version 10

275 software, and one-way ANOVA tests. Values of $p<0.05$ were taken to indicate a statistically 276 significant difference. 


\section{Results}

278

279

280

281

282

283

284

285

286

\subsection{Particle deposition fraction}

As expected, the deposition fraction on the test coil varied with particle size. For supermicron particles, the deposition fraction increased with increasing particle size for both dry and wet coils (see Figure 2). Across the diameter range 1.0 to $25 \mu \mathrm{m}$, the deposition fractions of particles were found to be higher than 0.11 (Figure 2(a)), with a maximum value of 0.65 for the wet coil and 0.50 for the dry coil. For smaller particles, in the diameter range $30 \mathrm{~nm}$ to $1.0 \mu \mathrm{m}$, deposition fractions were found to be small and not strongly dependent on particle size (Figure 2(a) and Figure S4). The monodispersed PSL particle deposition was also found to increase with increasing particle size, as shown in Figure 2(b). Increasing deposition rate with increasing size for supermicron particles is consistent with expectations, with inertial drift being the dominant particle transport process inducing deposition (Siegel and Nazaroff, 2003).

We observed that the deposition fraction was substantially higher onto wet coil surfaces than onto dry coils for supermicron particles, both for total ambient particles and for monodisperse PSL particles. Note that the four rows of fin-and-tube coil surfaces were dry and isothermal for the dry coil condition, but were wet with a continuous flow of condensing water for the wet coil condition. The tube surfaces for the wet coil were progressively cooler in the streamwise direction, ranging from $16{ }^{\circ} \mathrm{C}$ for Row 1 to $6{ }^{\circ} \mathrm{C}$ for Row 4 (Figure S2).

Two mechanisms could contribute to the higher deposition fraction on wet coil surfaces. First, condensed moisture on the cooling coil surfaces would produce a decreased channel width, inducing higher air speeds and lower travel distances, and thereby enhancing inertial impaction. A second possible contributor to enhanced particle deposition is faster transport toward the surface owing to one or both of thermophoresis, induced by the thermal gradient toward the cool coil surfaces, and diffusiophoresis, induced by the net flux of water vapor 
toward the condensing coil surface.

303

304

305

306

307

308

309

310

311

312

\subsection{Bioaerosol deposition fraction}

We found substantial bioaerosol particle deposition to the cooling coil, especially when cool and wet. Downstream air was found consistently to have lower DNA concentrations in bioaerosols than upstream air both for dry and wet coils (Figures 3 and 4). For the dry coil, the deposition fractions were small: 0.14 for total DNA, 0.18 for bacterial DNA and 0.22 for fungal DNA, respectively. By contrast, when the coil surfaces were cool and wet, with active water condensation from the air, the deposition fractions increased markedly: 0.51 for total DNA, 0.50 for bacterial DNA and 0.68 for fungal DNA, respectively. For the dry coils, the measured deposition fractions were not statistically different from zero $(p=0.25-0.38)$. However, for the wet coils, total, bacterial, and fungal DNA concentrations differed between the upstream and downstream sampling locations with statistical significance ( $p$-values $<$ $0.05)$.

The cooling coil exhibited similar removal effects for bacterial and fungal bioaerosol particles (Figure 4), although there was somewhat higher deposition for fungal DNA than for bacterial DNA. These measured differences might have been originated from different particle sizes. Fungal bioaerosols may be larger than particles containing bacterial DNA (Després et al., 2012), and, as we have shown for particles (Figure 2), larger particles exhibit a larger deposition fraction than do smaller particles in the supermicron size range.

Considering the data in Figures 3 and 4, we also found that the total bacterial and fungal DNA (71-355 fg of DNA per kg of dry air) contributed only a very small fraction of total DNA (64-70 pg of DNA per kg of dry air) to the air samples. In addition to microbial DNA, environmental DNA-containing bioaerosols can include pollen, viral DNA, vegetation debris and insect debris (Eduard et al., 2012).

We observed that the deposition of bioaerosols could also be affected by air speed 
through the test coil. Although the general patterns of fractional DNA deposition across the cooling coil were similar, the deposition fractions for air speeds of $1,1.5$ and $2 \mathrm{~m} / \mathrm{s}$ were distinguishable (Figures 3 and S5). For the dry coil, the deposition fraction of total bioaerosol DNA increased from 0.11 for an air speed of $1 \mathrm{~m} / \mathrm{s}$ to 0.16 for $2 \mathrm{~m} / \mathrm{s}$. On the cool, wet coil,

331 the deposition fraction of total DNA increased from 0.44 for an air speed of $1 \mathrm{~m} / \mathrm{s}$ to 0.54 for

$3322 \mathrm{~m} / \mathrm{s}$. Thus, higher air speeds produced more deposition for both dry and wet coils,

333 indicating that air speed is another parameter that affects biological particle deposition onto 334 cooling coil surfaces.

From the data presented in Figures 3 and 4, one can infer that 36 pg of total DNA (70 upstream vs. 34 downstream pg of DNA per kg of dry air), $189 \mathrm{fg}$ of fungal DNA (278 upstream vs. 89 downstream fg of DNA per kg of dry air), and 45 fg of bacterial DNA (90 upstream vs. 45 downstream fg of DNA per kg of dry air) would have been deposited onto wet cooling coil for every kg dry air passing through the cooling coil. Based on previous studies, 45 fg of bacterial DNA, for example, could correspond to approximately 9 bacterial

341 cells if using Escherichia coli as a standard (Nadkarni et al., 2002; Raghunathan et al., 2005).

342 As the cooling system was operated from 8 AM to 7 PM, one can estimate that the maximum 343 daily deposition for bacterial particles onto the tested cooling coil was 0.1 million bacterial

344 cells. If some proportion of these bacterial cells remain attached, remain viable and

345 reproduce, then some of the generated cell mass and/or the microbial metabolic byproducts

346 might be re-entrained into the air stream, potentially degrading indoor air quality.

\section{3.3. DNA collected in condensate water}

348 Figure 5 displays a time-series of DNA concentrations — total, bacterial, and fungal 349 from condensate water produced by the wet coil. Total DNA concentrations (10-13 ng/L) 350 were much higher than bacterial (0.04-0.2 ng/L) and fungal (0.01-0.3 ng/L) concentrations. 351 Both bacterial and fungal DNA contributed less than about 1\% of total DNA in the 
condensate water, similar to the airborne proportion. We also observed that bacterial DNA concentrations in the condensate water were much higher than the fungal concentrations, except for the first hour of the operation. The relative abundance of bacterial and fungal DNA in condensate water was different than their relative concentrations in the air ( $278 \mathrm{fg}$ of fungal DNA vs. $90 \mathrm{fg}$ of bacterial DNA per kg of dry air) as well as the respective reductions from the airstream (189 fg of fungal DNA vs. $45 \mathrm{fg}$ of bacterial DNA reduction per kg of dry air) as shown in Figure 4. Due to the fact that bacteria excel in replication and have much faster reproduction rates than fungi (Coleman, 1994; Kirchman, 2012), we speculate that a possible reason for the observation is that some previously deposited bacteria remained viable and might have reproduced on the coil surfaces, which then resulted in elevated bacterial DNA concentrations as compared with fungal DNA concentrations in the condensate water.

Total DNA and microbial DNA concentrations in the condensate water exhibited different time trends. The total DNA concentrations were fairly stable (ranging from 10 to $13 \mathrm{ng} / \mathrm{L}$ ) throughout the day. That result is consistent with a hypothesis that this DNA was in condensate water directly as a consequence of current deposition from air onto coil surfaces followed by an effective washing of the deposited DNA with the condensing water. In contrast, both bacterial and fungal DNA concentrations showed a downward trend with time during the course of a sampling day. This aspect was especially distinctive early: the concentration of microbial DNA in condensate water for the first hour of operation was an order of magnitude higher than the concentrations in later samples. A similar downward trend was also found for bacterial DNA concentrations in the condensate water produced by cooling coils from a commercial-building AHU (Figure S6).

A plausible explanation for this observation is that the microbial DNA was systematically higher in ambient air during the morning hours. However, it seems improbable that the 
difference in airborne microbial DNA levels with time of day would be sufficiently large to explain the condensate-water trends. An alternative possible explanation is that some of the deposited bacteria and fungi were viable and the viable microbes may have reproduced on cooling coil surfaces while the system was off overnight. It is feasible that viable bacteria and fungi deposited during the daytime grow on cooling coil surfaces during the night if environmental conditions (e.g., temperature, moisture, and nutrient levels) are suitable. Biodegradable organic matter from both the gas and particle phase could deposit on the cooling coil during operation providing a substrate for microbial growth. Considering the moist surfaces during operation, the persistently high RH and the chronically warm temperatures in Singapore, cooling coil surfaces might provide very good conditions for microbial growth during daily and/or weekly periods of ACMV system inoperation. A recent study in Singapore found evidence of rapid growth of Sphingomonas on a detergent-cleaned cooling coil surface, with a relative abundance of $5 \%$ in the first 3 days after the cleaning to a relative abundance of $30 \%$ in 11 th days after the cleaning, while its relative abundance in the upstream air was always smaller than 5\% (Acerbi et al., 2016).

\subsection{Measured and calculated DNA concentrations in condensate water}

Figure 6(a) compares measured and computed DNA concentrations in the condensate water for the first consecutive seven days of operation in the wet mode. The computed concentration ranged from 24 to $43 \mathrm{ng} / \mathrm{L}$. The measured concentration was more variable, ranging from 10 to $63 \mathrm{ng} / \mathrm{L}$, with a maximum value four times higher than the central tendency values shown in Figure 5. For the first four days, measured concentrations in the condensate water were elevated above the computed values. These elevated DNA collection rates at the early stage of wet coil operation might be explained by the measured values including not only the currently deposited materials from the air, but also contributions from the washing of previously accumulated DNA, e.g., from dry coil operation. Starting from the 
402 fifth day of wet coil operation, measured DNA concentrations in the condensate water began

403 to be lower than the calculated values, suggesting that some newly depositing bioaerosols

404 materials weren't being removed and remained in the test coil system. The difference

405 between the measured and calculated concentrations of DNA in condensate water shows a

406 steady downward trend (Figure 6(b)).

407 Interpreting the combined the data depicted in Figures 5 and 6, it appears that the 408 condensate water serves a cleaning function for the cooling coil system, removing a large 409 portion of the deposited biological materials from the cooling coil surfaces. However, it also

410 appears that some biological materials that deposit from the air remain in the cooling coil

411 system, at least temporarily. If some of the retained DNA is associated with viable microbes,

412 they could contribute to the fouling of heat exchanger surfaces, diminishing the designed 413 purpose of the heat exchanger and also potentially degrading indoor air quality.

414 4. Discussion

\subsection{Deposition fraction comparisons with literature}

416 Data regarding particle deposition on the test coil can be compared with previous

417 modeling and experimental studies (Siegel and Carey, 2001; Siegel, 2002; Siegel and

418 Nazaroff, 2003; Waring and Siegel, 2008). For example, Siegel and Nazaroff (2003) reported

419 that particle deposition on cooling coils should increase with increasing diameter and

420 increasing airspeed based on model predictions and experimental measurements, outcomes

421 that are qualitatively similar to the findings in the present work. The predicted deposition

422 fractions from that study are somewhat smaller than measured in the present study.

423 Contributing to the difference may be the geometries of the two heat exchangers as well as

424 the climatic factors in which these two studies were conducted. Based on modeling of

425 transport and deposition processes, previous studies also suggest that deposition of

426 supermicron particles should be enhanced to a wet cool coil surface as compared to a dry 
427

428

429

430

431

434

435

436

isothermal surface (Siegel, 2002; Waring and Siegel, 2008), a prediction that is qualitatively consistent with our experimental data, as shown in Figure 2.

The present study contributes new experimental data regarding bioaerosol deposition onto cooling coils. Although there is a literature discussing total particle deposition based on either modelling or experiments, there are no prior published studies that have directly assessed deposition of bioaerosol particles. Based on a mass-transport model, Siegel (2002) suggested that bioaerosols would have deposition fractions in the range $20-40 \%$ for cool, condensing coils with an air speed of $1.5 \mathrm{~m} / \mathrm{s}$. Here, we have obtained similar but somewhat higher experimental values. Because of the importance of particle size as an influencing factor, we anticipate that the DNA deposition fraction would vary in accordance with the varying bioaerosol size distributions in the airstream approaching the cooling coil. However, it remains a considerable challenge to measure the particle size distribution of microbial DNA in air (e.g., Yamamoto et al., 2014). In the absence of size-resolved data, the aggregate measures we report here may be useful as a basis for quantitative assessments.

\subsection{Microbial growth on cooling coil surfaces}

Previous studies have hypothesized that the moist areas on and around cooling coils may provide suitable conditions for microbial growth (Hugenholtz and Fuerst, 1992; Muyshondt et al., 1998; Levetin et al., 2001; Schmidt et al., 2012). Some studies have reported that the use of air-conditioners was associated with elevated levels of microorganisms in the indoor spaces, which was observed immediately after switching on the air conditioning (Abe, 1998; Hamada and Fujita, 2002; Jo and Lee, 2008). From the present work, the downward trend of bacterial and fungal DNA measured in condensate water over time (Figure 5) provides new experimental information supporting this hypothesis. In addition, the finding that the concentration in condensate water for the first hour was an order of magnitude higher than the concentrations at later times suggests the possibility of overnight reproduction of viable 
452 bacteria and fungi on the cooling coil surfaces.

453

454

455

456

457

458

459

460

461

462

463

464

465

466

467

468

469

470

471

472

473

474

475

\subsection{Is bioaerosol deposition on cooling coil surfaces good or bad?}

We found that deposition of particles and bioaerosols was substantial onto cooling coil surfaces. Cooling coil surfaces could contribute to the removal of particles and bioaerosols from the airflow, thereby contributing to lower airborne concentrations and associated human exposures in occupied spaces. Viewed narrowly, deposition on cooling coil might be considered a good outcome. However, particle and bioaerosol retention on cooling coil surfaces may also result in subsequent problems. One concern is increased energy requirements owing to the addition of thermal resistance associated with deposited materials and/or biofilms forming on the fin-and-tube heat exchanger, as has been suggested in previous studies (Siegel and Carey, 2001; Waring and Siegel, 2008; Wilson et al., 2013; Cremaschi and $\mathrm{Wu}, 2015)$. A second concern is reaerosolization of deposited materials and (potentially) the release of metabolic byproducts of microbes along with spores and fragments. This second concern, in which the cooling coil surface becomes a potential site for net bioaerosol emissions, was indicated by the work of Hugenholtz and Fuerst (1992). They found that post-coil air had much higher bacterial concentrations than pre-coil air. A third concern is the possible degradation of cooling coil surfaces caused by the deposited materials, which may contribute to a shortening of the useful life of these components in air conditioning systems.

\section{Conclusions}

People in indoor environments commonly inhale air that has contacted fin-and-tube heat exchangers. The interaction between the air and the cooling coils can influence indoor air quality. One important concern is bioaerosols. This investigation has provided new quantitative information regarding how fin-and-tube heat exchangers modify indoor 
476 bioaerosol air quality. We have primarily reported on the experimental deposition fractions of

477 bioaerosols measured across fin-and-tube cooling coils in a laboratory model of a core

478 portion of an air handling system. In this study, we found that the cooling coil is a substantial

479 sink for bioaerosols and exhibits similar deposition patterns for bacterial and fungal

480 bioaerosol particles. The fractional particle deposition depends on particle size, air speed and 481 operation mode of the cooling coil. We have also found that the flow of condensing water

482 from wet coils carries DNA at rates comparable to the rates of direct deposition from air. The

483 decreasing trend of bacterial and fungal DNA concentrations in the condensate water

484 provided suggestive evidence for microbial growth on heat exchanger surfaces during

485 overnight periods when the ventilation system was not operated. Comparing the measured

486 DNA concentrations in condensate water with calculated values based on DNA deposition

487 from the airstream, we also found evidence that some fraction of biological particles

488 remained on cooling coil surfaces, which may cause subsequent fouling and may also be a

489 source for indoor bioaerosols and their metabolic byproducts. These new data and the

490 interpreted insights are relevant to the hygienic design and operation of ACMV systems.

\section{Acknowledgements}

492 This work was funded by the Republic of Singapore's National Research Foundation 493 through a grant to the Berkeley Education Alliance for Research in Singapore (BEARS) for 494 the Singapore-Berkeley Building Efficiency and Sustainability in the Tropics (SinBerBEST) 495 Program. BEARS has been established by the University of California, Berkeley as a center 496 for intellectual excellence in research and education in Singapore.

\section{Appendix: Supplementary Information}

498 Supplementary information may be found in the online version of this article: 
499 Figure S1. (a) Temperature, (b) relative humidity and (c) air speed of the upstream and 500 downstream air with a wet cooling coil when the air speed was $1.5 \mathrm{~m} / \mathrm{s}$.

501 Figure S2. Time-resolved surface temperatures of four rows of cylindrical copper refrigerant 502 tubes with a wet coil when the air speed was $1.5 \mathrm{~m} / \mathrm{s}$.

503 Figure S3. Size-resolved particle concentrations of the ambient air, upstream and downstream 504 of the coil for the leakage test.

505 Figure S4. Deposition fractions of particles in the diameter range of $10-205 \mathrm{~nm}$ obtained by 506 SMPS.

507 Figure S5. The concentrations of DNA in bioaerosols sampled from air upstream and 508 downstream of the cooling coil when the air speeds were (a) $1 \mathrm{~m} / \mathrm{s}$ and (b) $2 \mathrm{~m} / \mathrm{s}$.

509 Figure S6. Bacterial DNA concentration in condensate water collected at different times for 510 three consecutive weeks from an air handling unit in a commercial building.

511 Table S1. Comparisons between in-line and open-face sampling methods for bioaerosols.

\section{References}

513 Abe, K., 1998. Fungal index and contamination in air conditioners when cooled. Journal of 514 the Society of Indoor Environment Japan 1, 41-50.

515 Acerbi, E., Chénard, C. Miller, D., Gaultier, N.E., Heinle, C.E., Chang, V.W.C., Uchida, A., 516 Drautz-Moses, D.I., Schuster, S.C., Lauro, F.M., 2016. Ecological succession of the 517 microbial communities of an air-conditioning cooling coil in the tropics. Indoor Air, 518 doi:10.1111/ina.12306.

519 Bluyssen, P.M., Cox, C., Seppänen, O., de Oliveira Fernandes, E., Clausen, G., Müller, B., 520 Roulet, C.A., 2003. Why, when and how do HVAC-systems pollute the indoor 521 environment and what to do about it? The European AIRLESS project. Building and 522 Environment 38, 209-225.

523 Chen, A., Cao, Q., Zhou, J., Yang, B., Chang, V.W.C., Nazaroff, W.W., 2016. Indoor and 524 outdoor particles in an air-conditioned building during and after the 2013 haze in 525 Singapore. Building and Environment, 99, 73-81. 
526 Coleman, D.C., 1994. The microbial loop concept as used in terrestrial soil ecology studies. Microbial Ecology 28, 245-250.

528 Cremaschi, L., Wu, X., 2015. Effect of fouling on the thermal performance of condensers and 529 on the water consumption in cooling tower systems. Heat Transfer Engineering 36, 663$530 \quad 675$.

531 Després, V.R., Huffman, J.A., Burrows, S.M., Hoose, C., Safatov, A.S., Buryak, G., 532 Fröhlich-Nowoisky, J., Elbert, W., Andreae, M.O., Pöschl, U., Jaenicke, R., 2012. 533 Primary biological aerosol particles in the atmosphere: A review. Tellus B 64, 15598.

534 Eduard, W., Heederik, D., Duchaine, C., Green, B.J., 2012. Bioaerosol exposure assessment in the workplace: The past, present and recent advances. Journal of Environmental Monitoring 14, 334-339.

537 Grigonyte, J., Nuutinen, I., Koponen, T., Lamberg, H., Tissari, J., Jokiniemi, J., Sippula, O., 538 2014. Evaluation of a heat exchanger designed for efficient fine particle precipitation in 539 small-scale wood combustion. Energy \& Fuels 28, 6058-6065.

540 Gröhn, A., Suonmaa, V., Auvinen, A., Lehtinen, K.E.J., Jokiniemi, J., 2009. Reduction of 541 fine particle emissions from wood combustion with optimized condensing heat exchangers. Environmental Science and Technology 43, 6269-6274.

543 Hamada, N., Fujita, T., 2002. Effect of air-conditioner on fungal contamination. Atmospheric Environment 36, 5443-5448.

545 Hugenholtz, P., Fuerst, J.A., 1992. Heterotrophic bacteria in an air-handling system. Applied 546 and Environmental Microbiology 58, 3914-3920.

547 Jo, W.K., Lee, J.H., 2008. Airborne fungal and bacterial levels associated with the use of 548 automobile air conditioners or heaters, room air conditioners, and humidifiers. Archives 549 of Environmental \& Occupational Health 63, 101-107.

550 Kirchman, D.L., 2012. Processes in Microbial Ecology. Oxford University Press.

551 Levetin, E., Shaughnessy, R., Rogers, C.A., Scheir, R., 2001. Effectiveness of germicidal UV 552 radiation for reducing fungal contamination within air-handling units. Applied and 553 Environmental Microbiology 67, 3712-3715. 
554 Liang, Y., Wu, Y., Sun, K., Chen, Q., Shen, F., Zhang, J., Yao, M., Zhu, T., Fang, J., 2012.

555

556

557

558

559

560

561

562

563

564

565

566

567

568

569

570

571

572

573

574

575

576

577

578

579

580

581

582 583 University of California, Berkeley. Rapid inactivation of biological species in the air using atmospheric pressure nonthermal plasma. Environmental Science and Technology 46, 3360-3368.

Liu, C.M., Kachur, S., Dwan, M.G., Abraham, A.G., Aziz, M., Hsueh, P.R., Huang, Y.T., Busch, J.D., Lamit, L.J., Gehring, C.A., Keim, P., Price, L.B., 2012. FungiQuant: a broad-coverage fungal quantitative real-time PCR assay. BMC Microbiology 12, 255.

Luhung, I., Wu, Y., Ng, C.K., Miller, D., Cao, B., Chang, V.W.C., 2015. Protocol improvements for low concentration DNA-based bioaerosol sampling and analysis. PloS One $10, \mathrm{e} 0141158$.

Muyshondt, A., Nutter, D., Gordon, M., 1998. Investigation of a fin-and-tube surface as a contaminant sink. ASHRAE IAQ 98, Proceedings of the ASHRAE Conference on Indoor Air Quality, American Society of Heating, Refrigerating, and Air-Conditioning Engineers, Atlanta, GA, pp 207-211.

Nadkarni, M.A., Martin, F.E., Jacques, N.A., Hunter, N., 2002. Determination of bacterial load by real-time PCR using a broad-range (universal) probe and primers set. Microbiology 148, 257-266.

Pongsoi, P., Pikulkajorn, S., Wongwises, S., 2014. Heat transfer and flow characteristics of spiral fin-and-tube heat exchangers: A review. International Journal of Heat and Mass Transfer 79, 417-431.

Raghunathan, A., Ferguson, H.R., Bornarth, C.J., Song, W., Driscoll, M., Lasken, R.S., 2005. Genomic DNA amplification from a single bacterium. Applied and Environmental Microbiology 71, 3342-3347.

Rim, D., Schiavon, S., Nazaroff, W.W., 2015. Energy and cost associated with ventilating office buildings in a tropical climate. PloS One 10, e 0122310.

Schmidt, M.G., Attaway, H.H., Terzieva, S., Marshall, A., Steed, L.L., Salzberg, D., Hamoodi, H.A., Khan, J.A., Feigley, C.E., Michels, H.T., 2012. Characterization and control of the microbial community affiliated with copper or aluminum heat exchangers of HVAC systems. Current Microbiology 65, 141-149.

Siegel, J.A., 2002. Particulate fouling of HVAC heat exchangers, Doctoral dissertation, 
584 Siegel, J., Carey, V.P., 2001. Fouling of HVAC fin and tube heat exchangers. Report LBNL47668, Lawrence Berkeley National Laboratory, Berkeley, California, USA.

586 Siegel, J.A., Nazaroff, W.W., 2003. Predicting particle deposition on HVAC heat exchangers. 587 Atmospheric Environment 37, 5587-5596.

588 Siegel, J., Walker, I., 2001. Deposition of biological aerosols on HVAC heat exchangers. 589 Report LBNL-47669, Lawrence Berkeley National Laboratory, Berkeley, California, $590 \quad$ USA.

591 Tang, L.H., Tan, S.C., Gao, P.Z., Zeng, M., 2016. Parameters optimization of fin-and-tube 592 heat exchanger with a novel vortex generator fin by Taguchi method. Heat Transfer 593 Engineering 37, 369-381.

594 Waring, M.S., Siegel, J.A., 2008. Particle loading rates for HVAC filters, heat exchangers, 595 and ducts. Indoor Air 18, 209-224.

596 Wilson, E.J.H., McNeill, J.S., Zhai, Z., Krarti, M., 2013. A parametric study of energy 597 savings from cleaning coils and filters in constant air volume HVAC systems. HVAC\&R $598 \quad$ Research 19, 616-626.

599 Wu, Y., Yao, M., 2010. Inactivation of bacteria and fungus aerosols using microwave 600 irradiation. Journal of Aerosol Science 41, 682-693.

601 Yamamoto, N., Nazaroff, W.W., Peccia, J., 2014. Assessing the aerodynamic diameters of 602 taxon-specific fungal bioaerosols by quantitative PCR and next-generation DNA 603 sequencing. Journal of Aerosol Science 78, 1-10. 


\section{Figures}

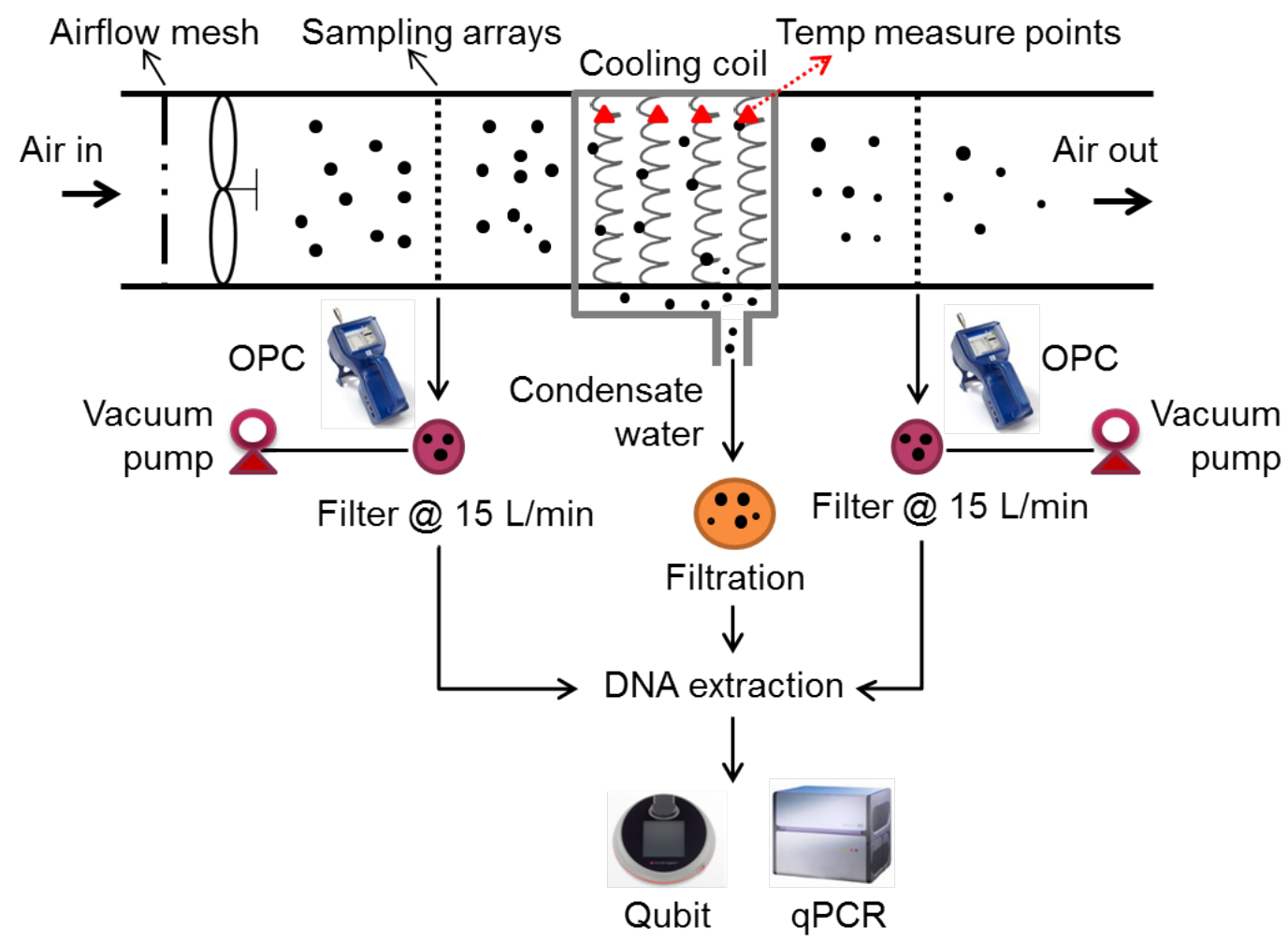

606 Figure 1. Schematic diagram of system for studying particle and bioaerosol deposition onto 607 an air-conditioning cooling coil.

608 
(a)

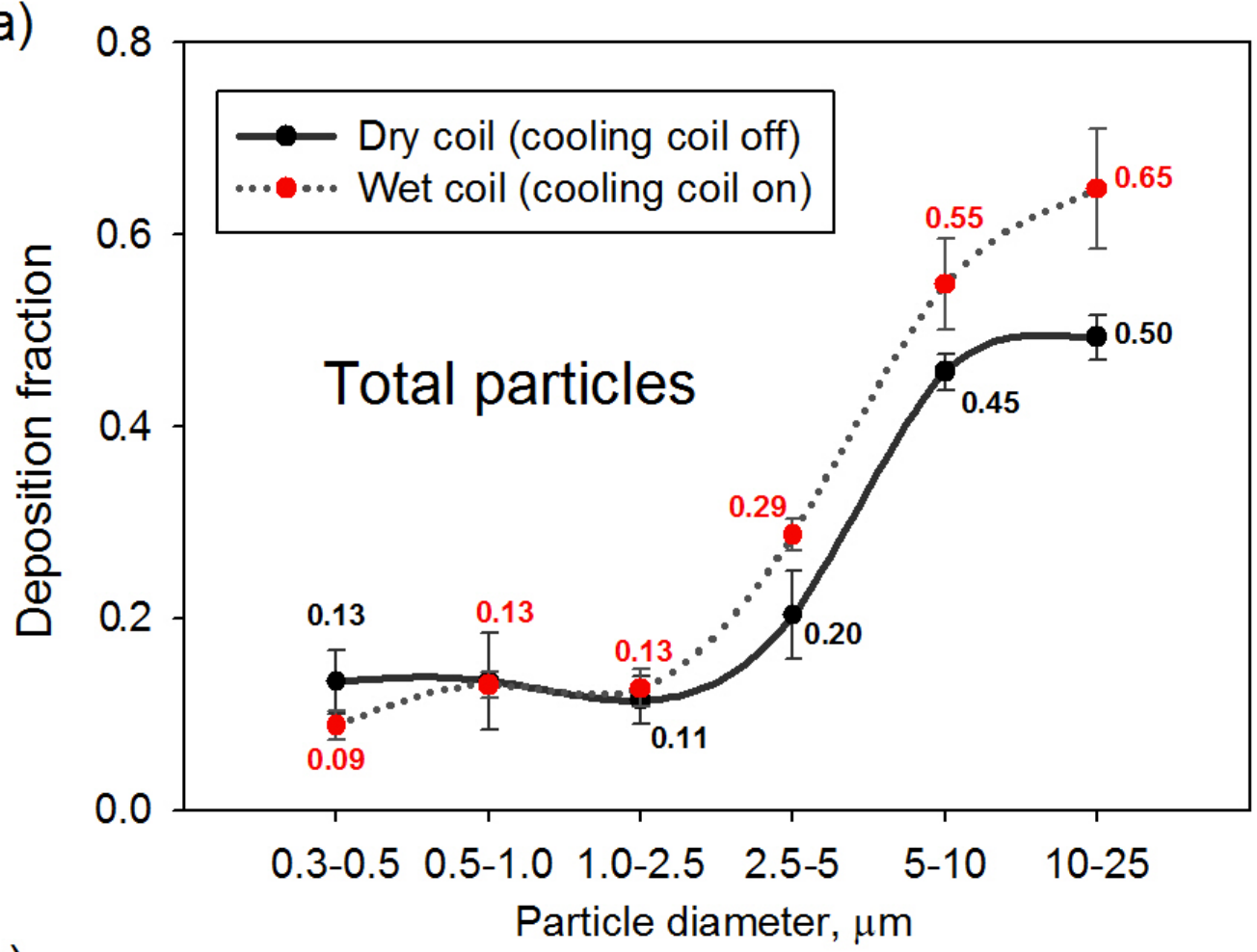

(b)

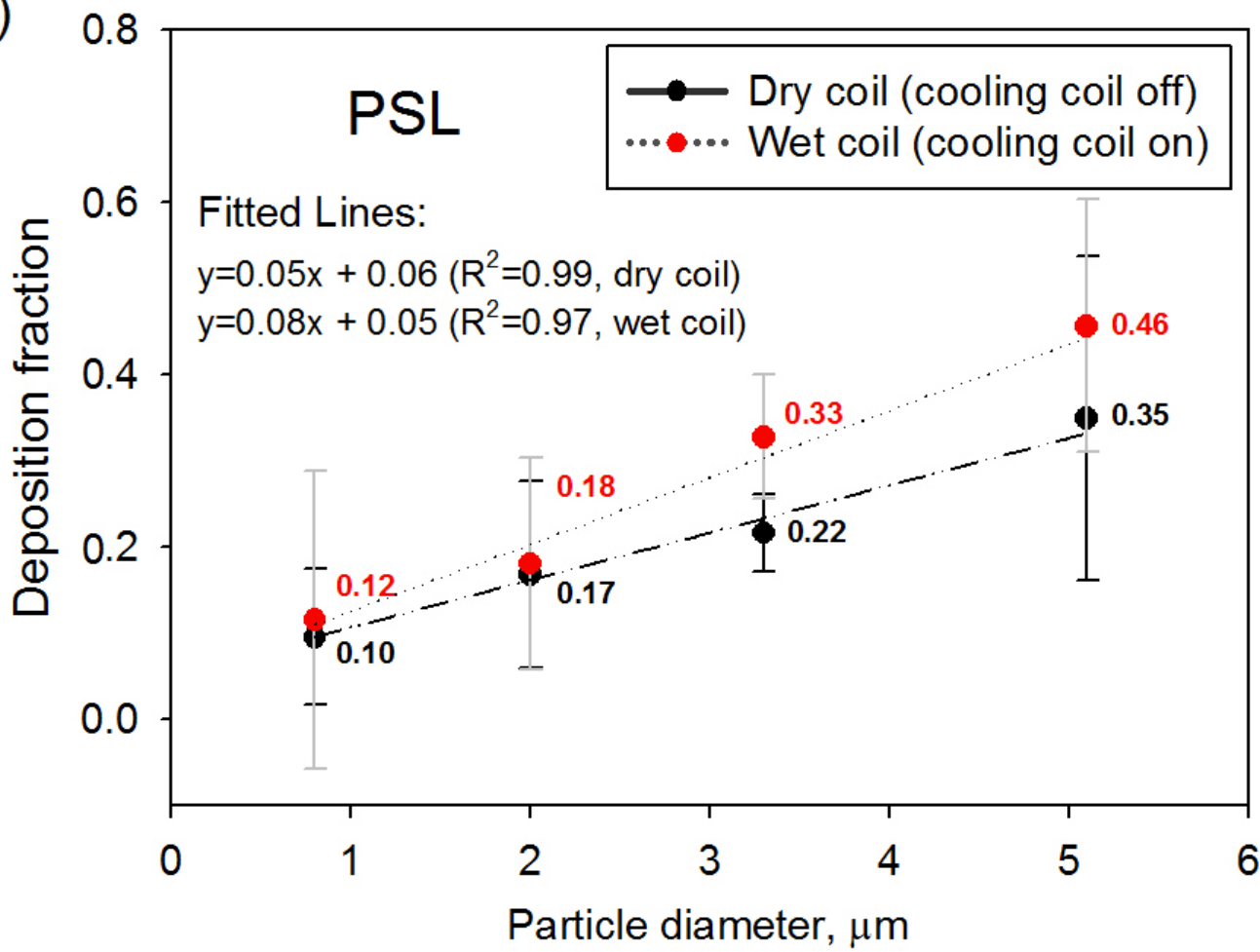

Figure 2. Deposition fractions of (a) total size-resolved particles and (b) monodisperse

611 polystyrene latex (PSL) particles (diameters $=0.8,2.0,3.3$ and $5.1 \mu \mathrm{m}$ ) onto the cooling coil when the air speed was $1.5 \mathrm{~m} / \mathrm{s}$. In (b), lines indicate the best-fit linear correlation between deposition fraction $(y)$ and particle diameter $(x, \mu \mathrm{m})$. Data points represent averages of nine independent repeated experiments and error bars represent the standard deviations. Numbers labeling the points indicate the mean particle deposition fractions under different cooling coil operation conditions. 
618

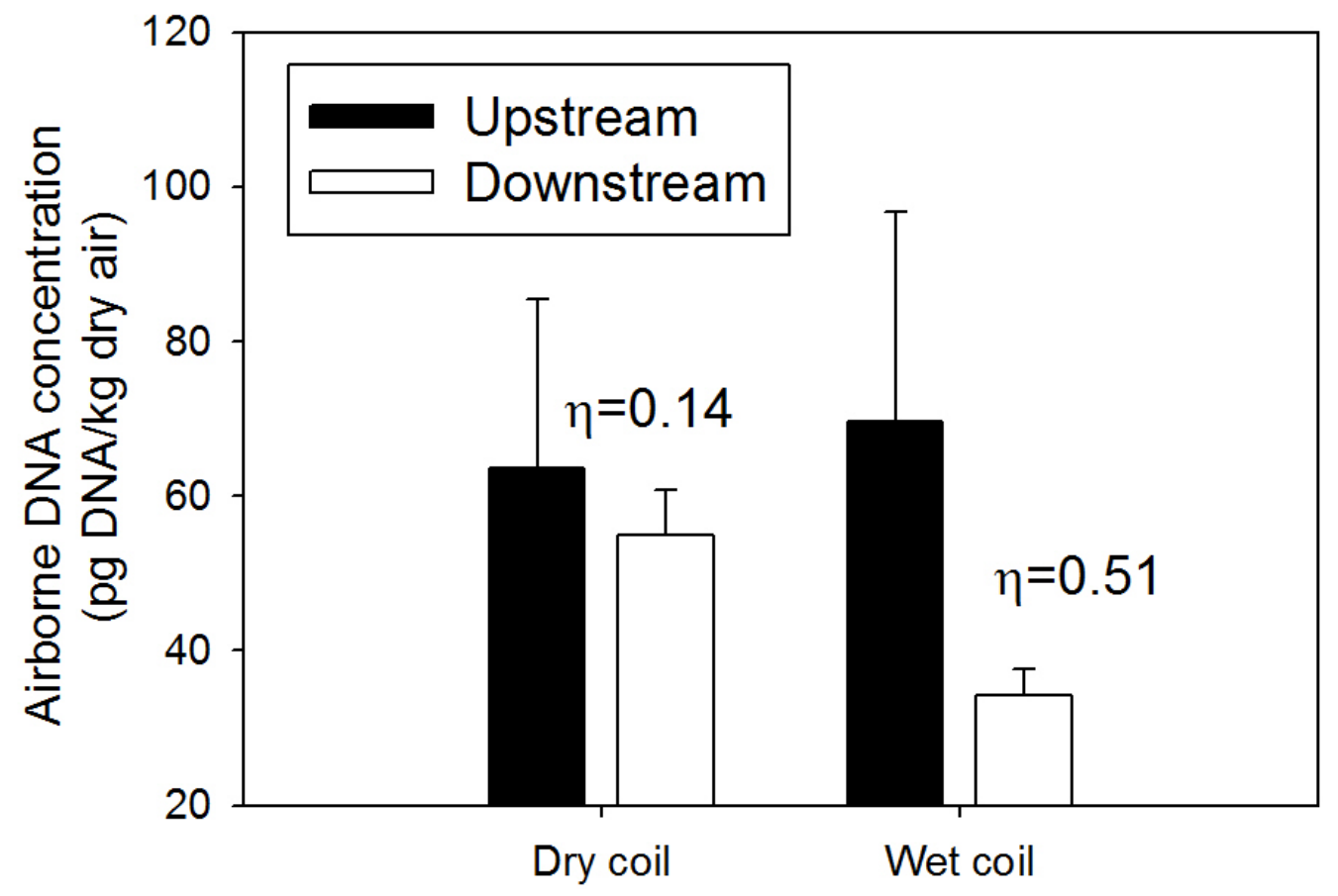

619 Figure 3. The concentrations of DNA in bioaerosols sampled from air upstream and 621 downstream of the cooling coil when the air speed was $1.5 \mathrm{~m} / \mathrm{s}$. The symbol $y$ represents the 622 DNA deposition fraction on the cooling coil. Data points represent averages of nine 623 independent repeated experiments and error bars represent the standard deviations.

624 
(a)

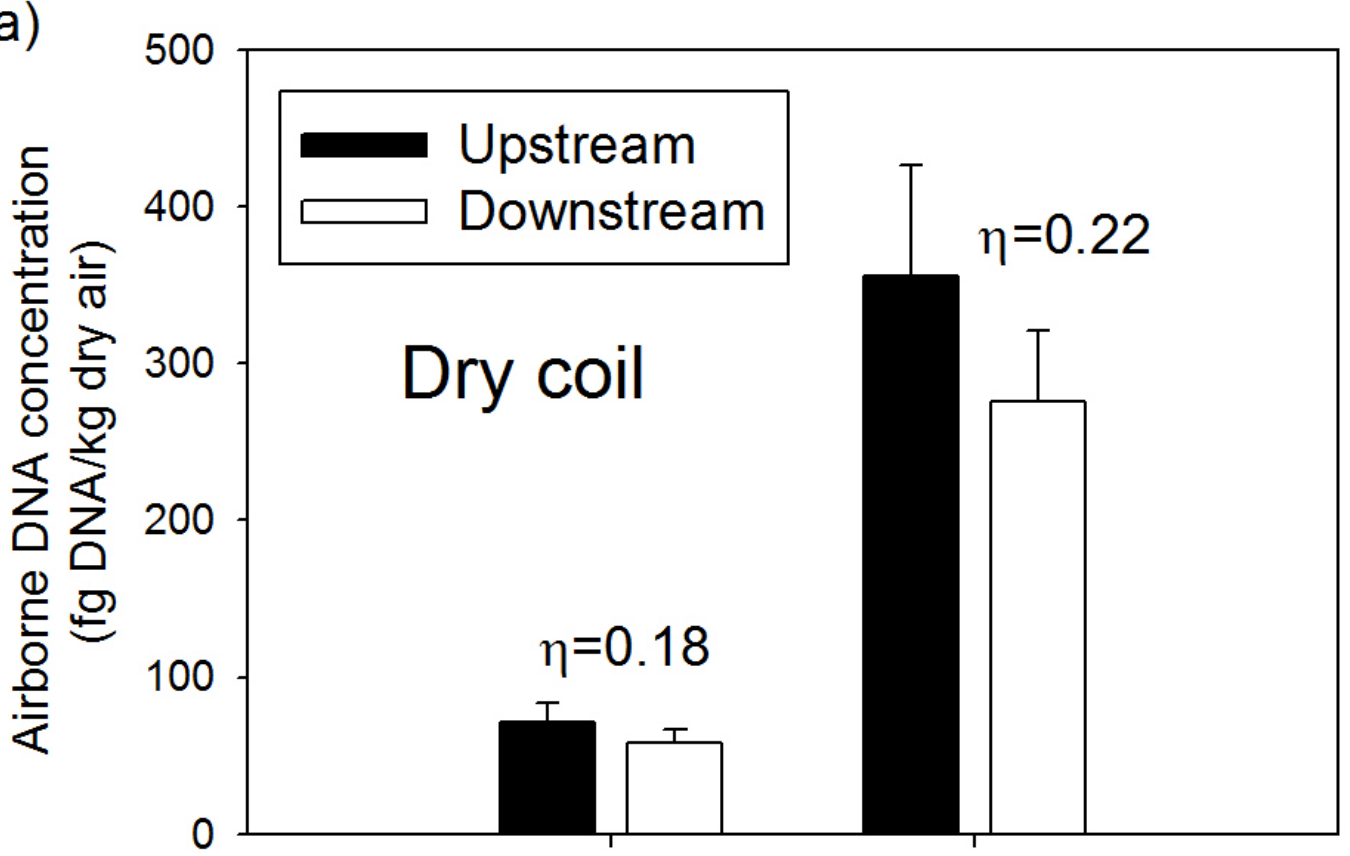

(b)

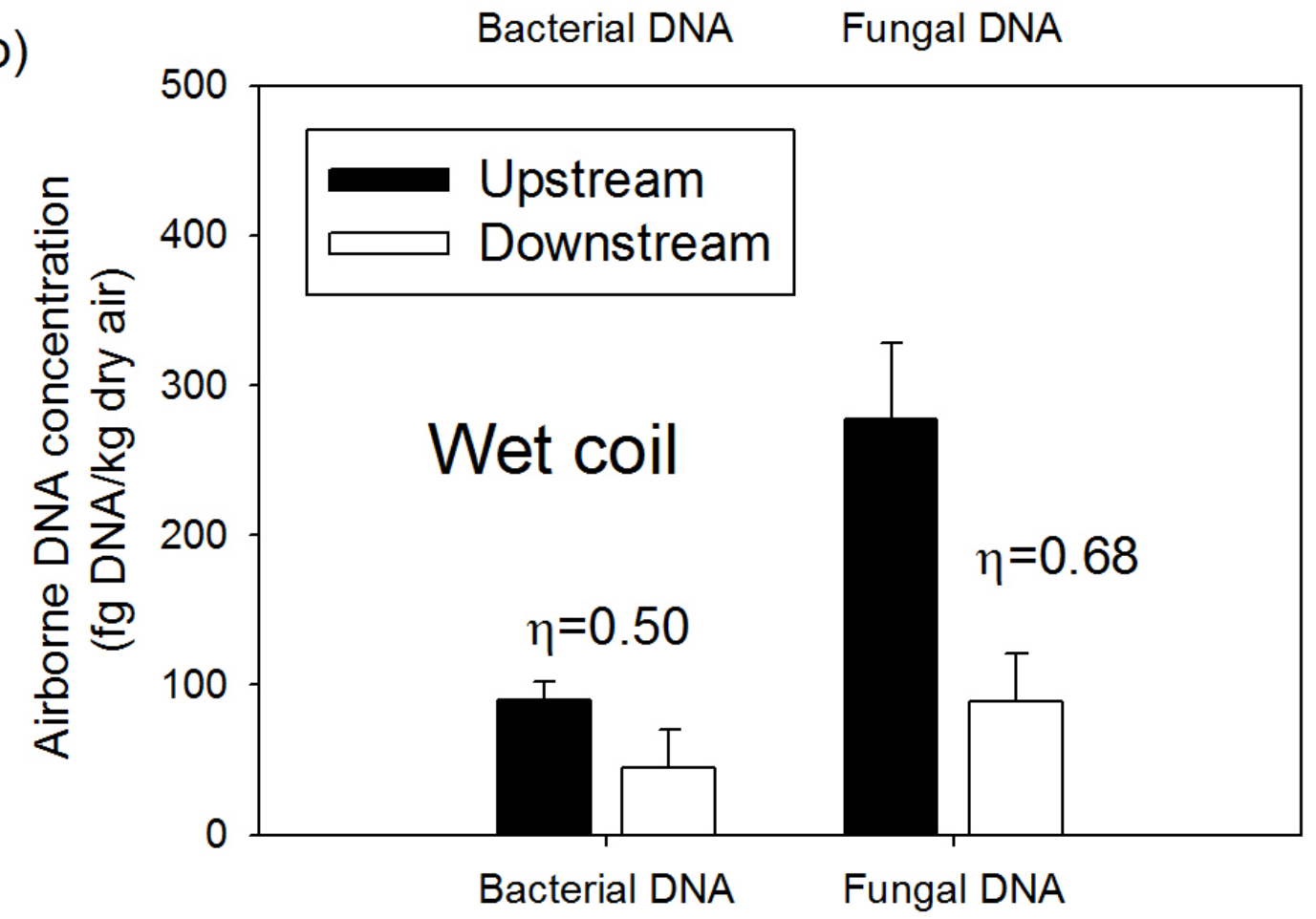

627 Figure 4. Concentrations of airborne bacterial and fungal DNA sampled upstream and 628 downstream of (a) dry coil and (b) wet coil. The symbol $\eta$ represents the DNA deposition 629 fraction on the cooling coil. Data points represent averages of nine independent repeated 630 experiments and error bars represent the standard deviations. 


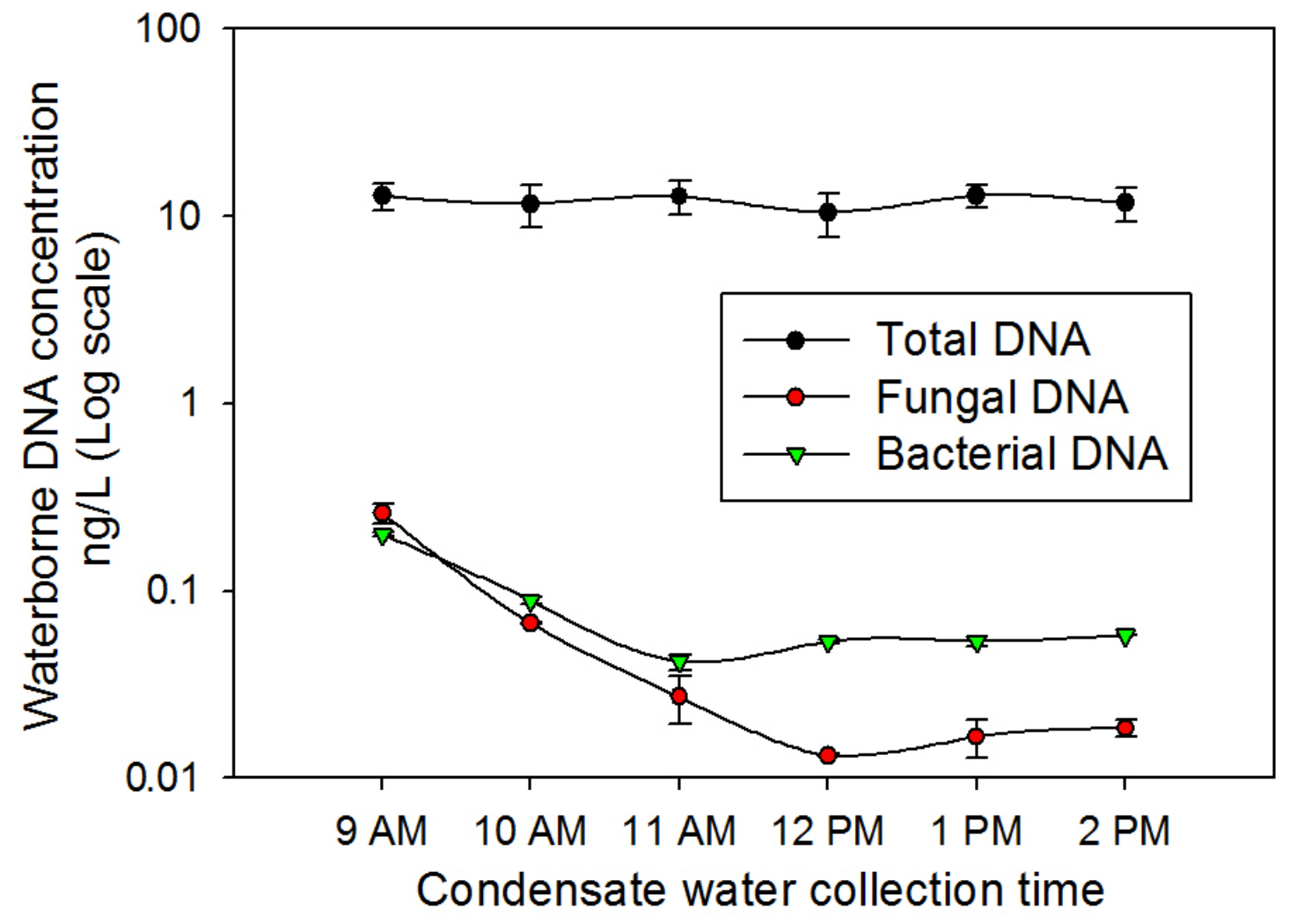

633 Figure 5. Time-series concentrations of total (microbial plus non-microbial), bacterial and 634 fungal DNA in condensate water collected at different daily times with the cooling coil 635 operating for 11 hours per day (from 8 AM to $7 \mathrm{PM}$ ). Times are referenced to the collection 636 time of condensate water in one day's operation. Data points represent averages of six 637 independent repeated experiments and error bars represent the standard deviations. 
(a)

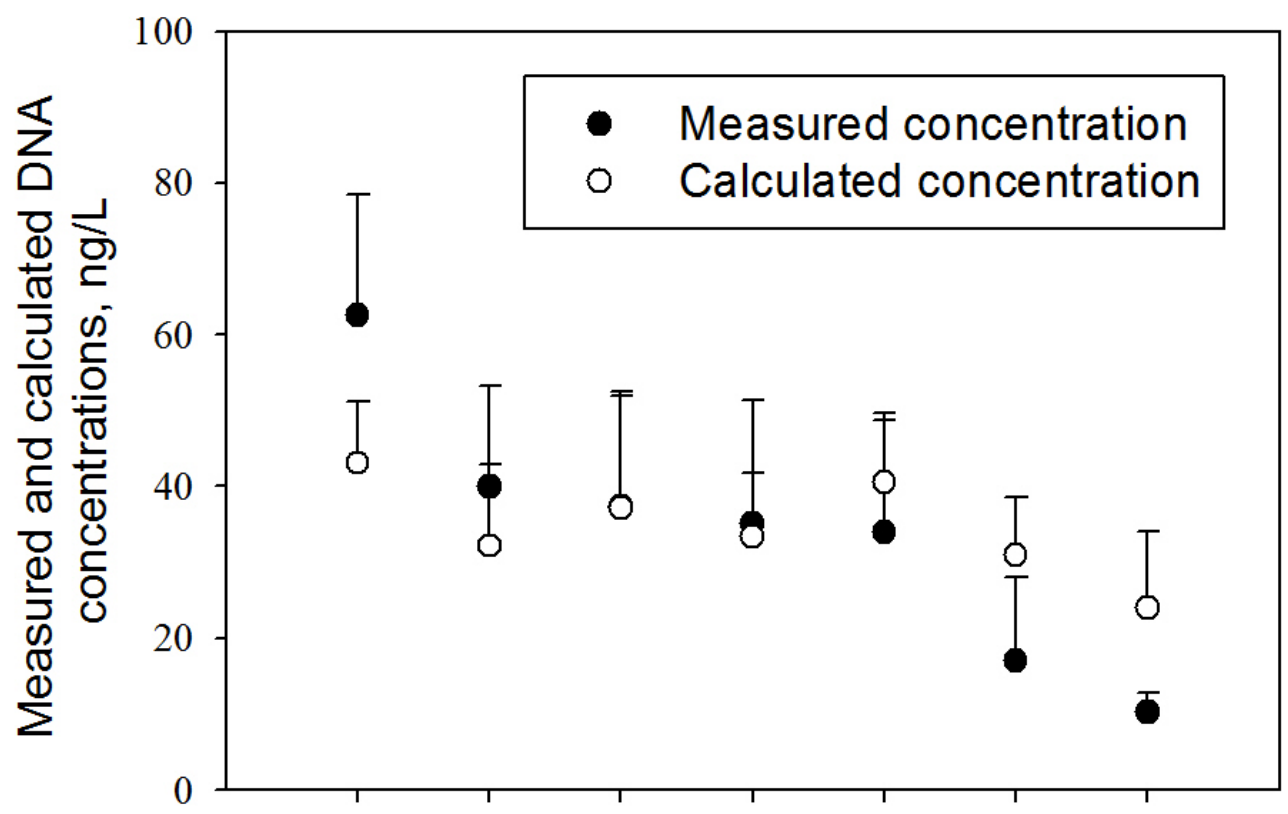

(b)

Day 1 Day 2 Day 3 Day 4 Day 5 Day 6 Day 7

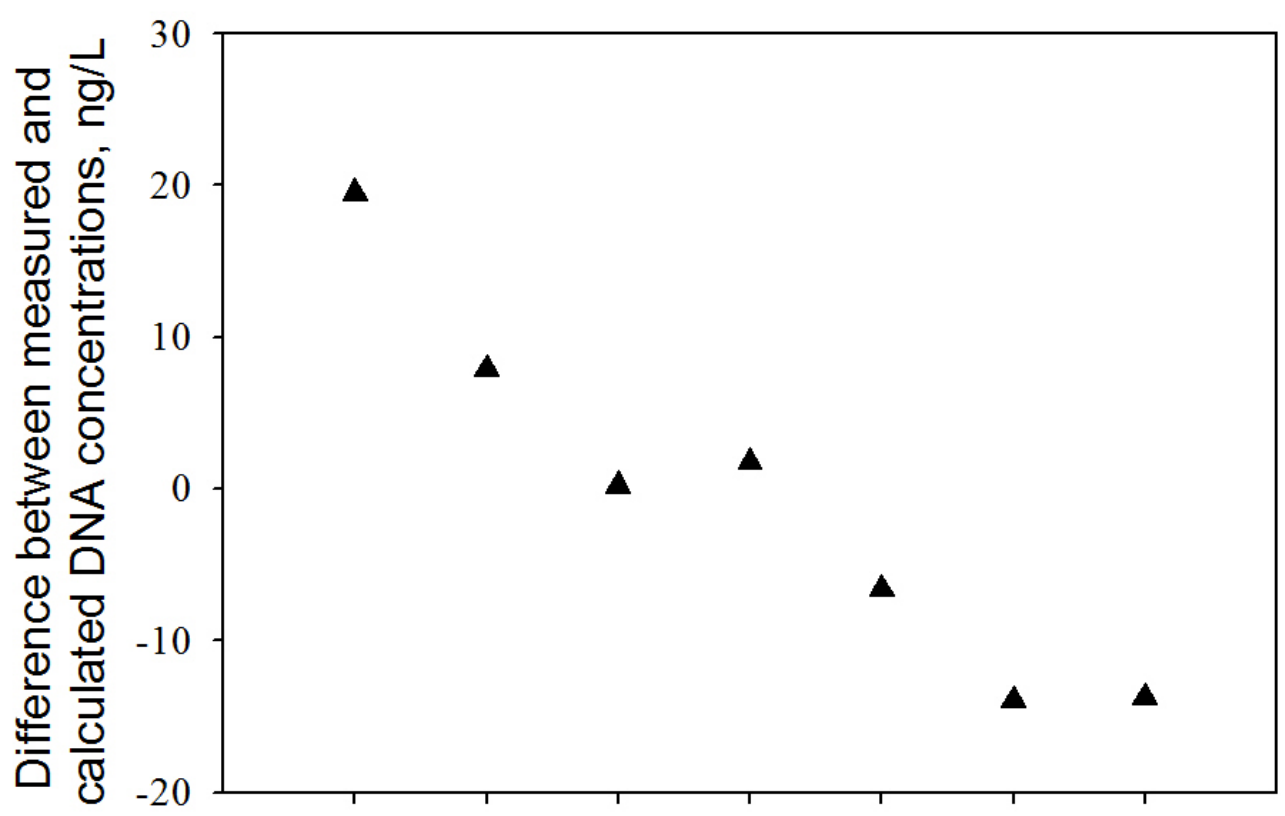

Day 1 Day 2 Day 3 Day 4 Day 5 Day 6 Day 7

640 Figure 6. (a) Measured and calculated DNA concentrations in condensate water samples for 641 seven days of continuous operation of the cooling coils. (b) Difference between measured 642 and calculated DNA concentrations in condensate water. Before Day 1, the dry cooling coil 643 had been continually on during daytime for about two weeks. For the seven-day experimental 644 period, the cooling system as well as the fan were operated for 11 hours per day starting at 8 $645 \mathrm{AM}$, and were off for all other times. For each of seven test days, $3 \times 1 \mathrm{~L}$ of condensate water 646 was collected at intervals of $60 \mathrm{~min}$ (collection times $=9$ AM through $2 \mathrm{PM}$ ) and analyzed as described in $\$ 2.6$. Data points represent averages of three independent repeated experiments 